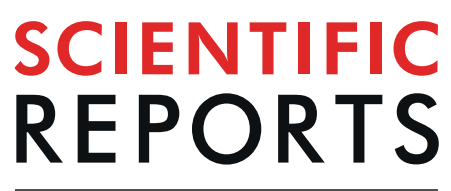

natureresearch

\title{
OPEN
}

Published online: 02 April 2020

\section{Author Correction: PHF14: an innate inhibitor against the progression of renal fibrosis following folic acid-induced kidney injury}

\author{
BoYang, Sixiu Chen, Ming Wu, Lin Zhang, Mengna Ruan, Xujiao Chen, Zhengjun Chen, \\ Changlin Mei \& Zhiguo Mao
}

Correction to: Scientific Reports https://doi.org/10.1038/srep39888, published online 03 January 2017

This Article contains an error in the Acknowledgements section.

“This work was supported by the National Nature Science Fund of China (No. 81000281, 31430055, 31190062, and 31170723), Chinese Society of Nephrology (No. 13030340419), Major Fundamental Research Program of Shanghai Committee of Science and Technology (No. 12DJ1400300), and Key Projects in the National Science \& Technology Pillar Program in the Twelfth Five-year Plan Period (No. 2011BAI10B00).”

should read:

“This work was supported by the National Natural Science Foundation of China (No. 81570621, 81000281, 31430055, 31190062, and 31170723), Chinese Society of Nephrology (No. 13030340419), Major Fundamental Research Program of Shanghai Committee of Science and Technology (No. 12DJ1400300), and Key Projects in the National Science \& Technology Pillar Program in the Twelfth Five-year Plan Period (No. 2011BAI10B00).”

(i) Open Access This article is licensed under a Creative Commons Attribution 4.0 International C. License, which permits use, sharing, adaptation, distribution and reproduction in any medium or format, as long as you give appropriate credit to the original author(s) and the source, provide a link to the Creative Commons license, and indicate if changes were made. The images or other third party material in this article are included in the article's Creative Commons license, unless indicated otherwise in a credit line to the material. If material is not included in the article's Creative Commons license and your intended use is not permitted by statutory regulation or exceeds the permitted use, you will need to obtain permission directly from the copyright holder. To view a copy of this license, visit http://creativecommons.org/licenses/by/4.0/.

(C) The Author(s) 2020 